\title{
Lidocaine Hydrochloride Ophthalmic Gel
}

National Cancer Institute

\section{Source}

National Cancer Institute. Lidocaine Hydrochloride Ophthalmic Gel. NCI Thesaurus. Code C132682.

An ophthalmic gel formulation containing the synthetic amide-type anesthetic lidocaine, with potential analgesic activity. Upon ophthalmic application, the active ing redient lidocaine binds to and blocks voltage-gated sodium channels in neuronal cell membranes. Lidocaine-mediated stabilization of neuronal membranes inhibits the initiation and conduction of nerve impulses, which numbs the nerves, prevents the trigemino-cardiac reflex and produces a reversible local anesthesia. 